\title{
MINDAZERIUS DOMINICANUS NOV. GEN., NOV. SP., A FOSSIL APHID (HOMOPTERA, APHIDOIDEA, DREPANOSIPHIDAE) FROM DOMINICAN AMBER
}

\author{
By Ole E. Heie ${ }^{1} \&$ George O. Poinar, Jr. ${ }^{2}$
}

\section{INTRODUCTION}

A range of animals-insects, spiders, frogs, lizards and mammalian hair-have been represented in Dominican amber (Poinar \& Cannatella 1987, Poinar 1988), but until now no aphids. One of us (G. O. Poinar) found a single remarkable specimen after sorting through some 20,000 pieces. It is placed in a new genus within the tribe Lizerini.

The fossil resembles species of Mindarus Koch, a genus represented by more Tertiary than extant species. However, it also shares characters with Lizerius Blanchard and Paoliella Theobald, both recent, but presumably primitive genera of the family Drepanosiphidae.

The present fossil originated from mines located either in the northern or eastern portion of the Dominican Republic. Sedimentary and geological evidence indicates a range from Upper Eocene to Lower Miocene for the amber mines in these regions (Lambert et al. 1985, Poinar \& Cannatella, 1987). Dominican amber originated from leguminous trees of the genus Hymenaea (Hueber \& Langenheim, 1986). Chemical and physical tests (Poinar 1982) performed on the piece verified that it was authentic amber.

The aphid occurred in a small piece of transparent yellow amber with several small air bubbles. Its body and appendages were undamaged and easily observed (except for the anterior part of the abdominal dorsum, which was covered by parts of the wings and a narrow film of air) (Fig. 1). Antennae, wings, and some of the legs were stretched out, so that measurements could easily be made. A binocular Zeiss-Winkel microscope with a $10 \times$ objective was used

'Institute of Biology, DLH, Emdrupvej 101, DK-2400 Copenhagen NV, Denmark. 2Division of Entomology and Parasitology, University of California, Berkeley, California 94720, USA

Manuscript received by the editor September 6, 1988. 


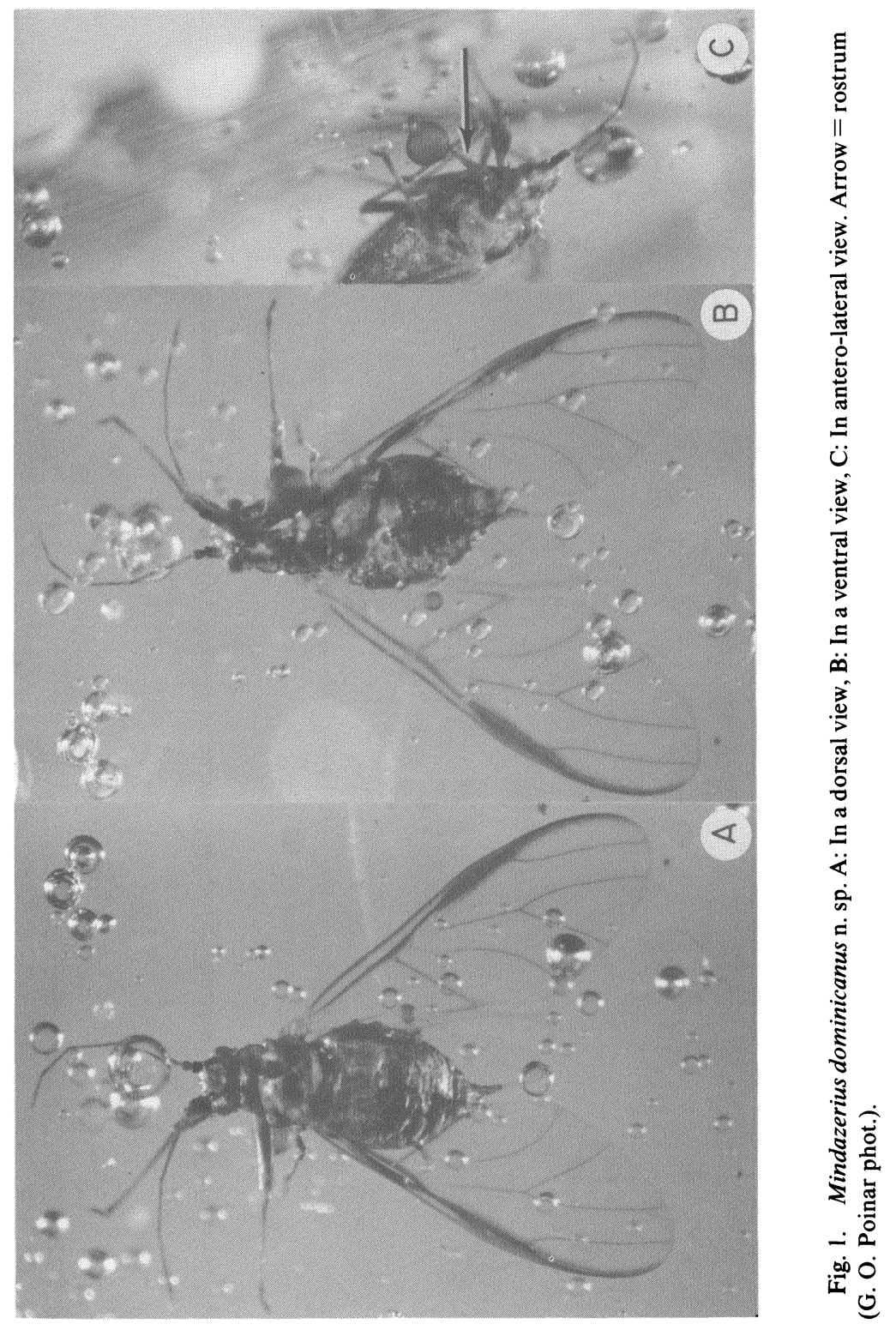


for the description. Placing the amber piece in mineral oil facilitated microscopic observation.

\section{DESCRIPTION}

Mindazerius gen. nov.

Wing venation as in Mindarus Koch (Fig. 3). Pterostigma long, slender, reaching apex of the fore wing; radial sector long and nearly straight, leaving the proximal half of pterostigma; media with one fork; cubitus branches leaving main vein at separate points, the distal one curved backwards; siphunculi present, short, but rather well developed, truncate, broad at base; cauda rather long and slender; processus terminalis of antenna about half as long as basal part of ultimate antennal segment; fore femur much thicker than hind femur.

Main differences from Lizerius and Paoliella: Anal plate not biolobed; cauda not distinctly knobbed.

Monotypic. Type-species: Mindazerius dominicanus sp. nov.

\section{Mindazerius dominicanus sp. nov.}

Body length $1.6 \mathrm{~mm}$ (Fig. 2). Largest width of abdomen $0.68 \mathrm{~mm}$. Frons with three small tubercles placed between antennal bases; width of head across eyes $0.37 \mathrm{~mm}$, indistinct lines on the underside of the head may be interpreted as part of the epicranial suture (Fig. 11). Eyes very large, semiglobular, with distinctly separated, rather large ocular tubercles; longitudinal diameter of eye $0.11 \mathrm{~mm}$ excluding the tubercle, $0.13 \mathrm{~mm}$ including the ocular tubercle. Ocelli with dark rims. Antenna 6-segmented, $0.7 \times$ body; lengths of segments in $\mathrm{mm}$ : I-0.07, II-0.07, III-0.35, IV-0.26-0.27, V-0.21-0.22, VIa-0.11, VIb-(processus terminalis) $0.055-0.065$; processus terminalis $0.5-0.6$ $X$ basal part of VIth segment (VIa), 0.16-0.19 $\times$ segm. III; segm. IV-0.74-0.78 $\times$ III; V-0.61-0.62 $\times$ III; VI-0.47-0.49 $\times$ III; segm. III with 7 subcircular secondary rhinaria in a row on the slightly thickened proximal two-thirds (Fig. 6); the other segments without secondary rhinaria. Rostrum rather short, about $0.4 \mathrm{~mm}$ long $(0.3$ in an oblique view from the polished plane of the amber piece; $0.3 \times$ square root of $2=0.42$ ), nearly reaching to middle coxae, rather slender; apical segment about $0.07 \mathrm{~mm}$, of about the same length as segment II of hind tarsus. 


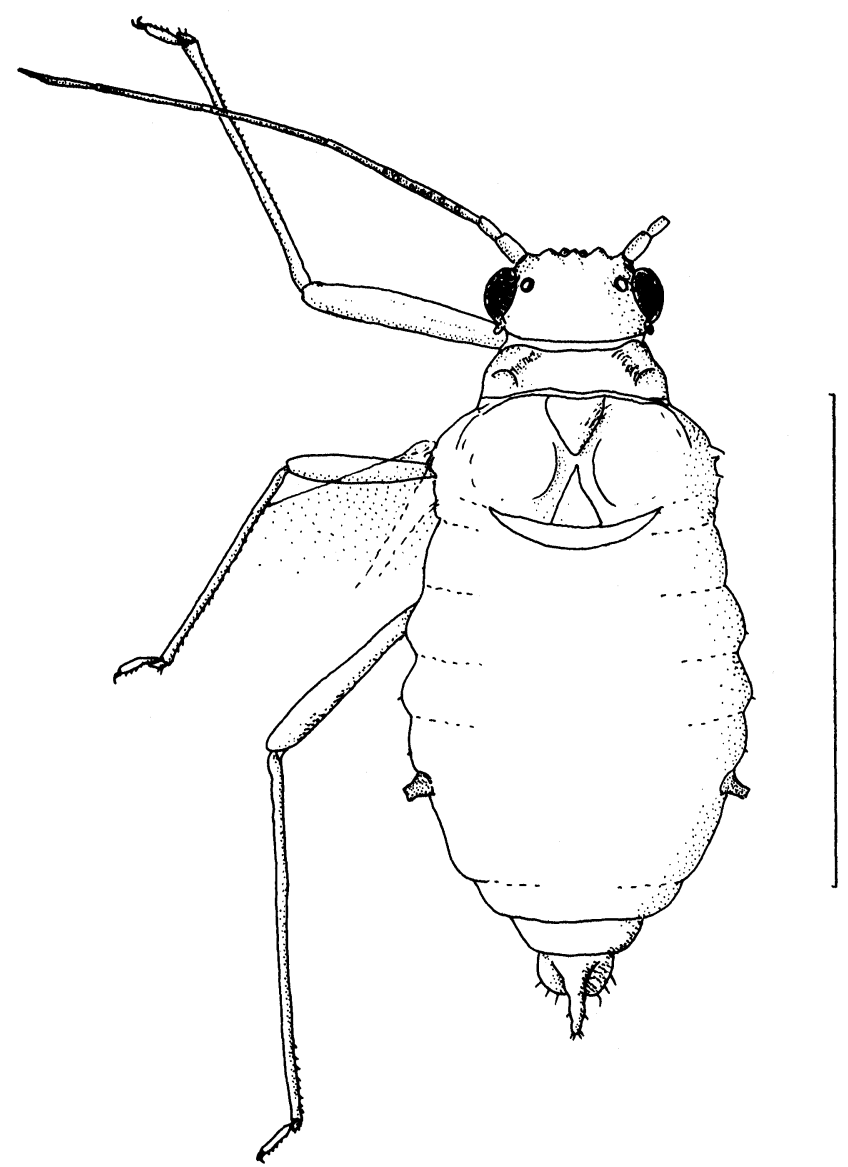

Fig. 2. Mindazerius dominicanus $\mathrm{n}$. sp. Body (wings not drawn) in a dorsal view. Reconstruction. Scale: $1 \mathrm{~mm}$.

Posterior margin of pronotum slightly curved, nearly straight; mesothoracic lobes well developed, indicating roof-like position of wings in repose; triangular field between the posterior parts of these lobes (but it is impossible to see if it is membranous); fore femora as long as hind femora, thicker than middle and hind femora, about $1.8 \times$ width of hind femora (Figs. 7 and 8); lengths in $\mathrm{mm}$ : fore femur 0.46 , hind femur $0.45-0.46$, fore tibia 0.53 , middle tibia 0.47 , hind tibia 0.75 , tarsi (tarsal claws excluded) 0.09-0.10, segment II of 
hind tarsus about 0.062 ; widths in the middle in $\mathrm{mm}$ : fore femur 0.072 , middle femur 0.060 , hind femur about 0.04 , fore tibia about 0.02 , middle and hind tibiae 0.025 . Hairs on tibiae short, as long as basal diameter of antennal segment III or shorter. First tarsal segments with several hairs (more than 3). Fore wing (Fig. 3) $2.28 \mathrm{~mm}$ long; length of the slender pterostigma about $1.13 \mathrm{~mm}$; radial sector nearly straight, leaving the basal part of pterostigma $0.74 \mathrm{~mm}$ from its apex, reaching the apex of the wing $0.09 \mathrm{~mm}$ below the apex of the pterostigma; media about $1.0 \mathrm{~mm}$ long, with invisible proximal part and one fork, the proximal branch of the fork being $0.53 \mathrm{~mm}$ long; cubitus-branches leaving the main vein from points $0.13 \mathrm{~mm}$ apart, the distal branch strongly curved, the proximal branch nearly straight and more strongly pigmented. Hind wing (Fig. 4) about 1.3 $\mathrm{mm}$ long, with two oblique veins.

Dorsum of the anterior abdominal segments covered by parts of the wings and a film of air. Sclerotization and pigmentation of abdomen unknown. Presence or absence of dorsal body hairs and wax glands impossible to detect. Tergites I-IV with low, broad, rounded marginal tubercles, each carrying a very short hair or spinule (Fig. 2). Siphunculi truncate, about $0.05 \mathrm{~mm}$ long, about 0.085 $\mathrm{mm}$ broad at base, $0.037 \mathrm{~mm}$ broad at apex, situated rather far from each other in nearly lateral positions and rather far ahead, near the middle of the margins of abdominal segment $\mathrm{V}$, and without distinct flanges (Fig. 2). Drops of fluid from the siphunculi present at their apices. Cauda finger- or sausage-shaped, nearly cylindrical, about $0.14 \mathrm{~mm}$ long, about $0.04 \mathrm{~mm}$ broad in the middle, with at least 6 rather short, pointed hairs, two pairs being placed at the blunt apex and the remaining two hairs placed closer to the middle in lateral positions (Figs. 9 and 10). It is impossible to see if the cauda is slightly constricted at base or not constricted at all. Anal plate apparently with nearly straight posterior margin or slightly emarginated (partly covered by an air bubble) (Fig. 9).

\section{Holotype}

The holotype is included in an amber piece labelled "No. HO 4-7, Mindazerius dominicanus Heie \& Poinar, Holotype" in the Poinar collection of Dominican amber housed at the University of California, Berkeley, California, USA.

Type-locality

Amber mine in the Dominican Republic. 


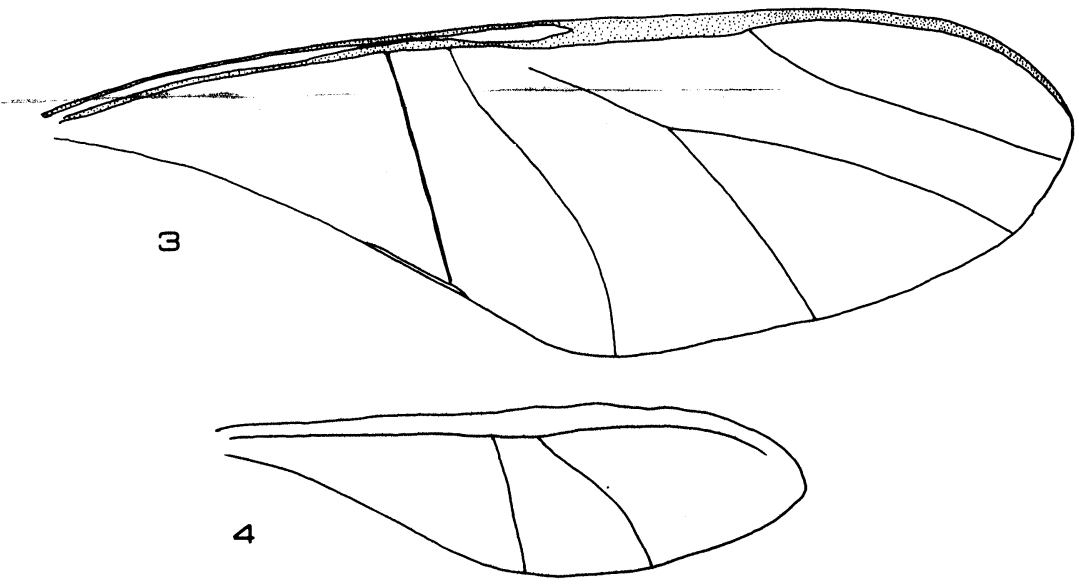

Fig. 3 and 4. Mindazerius dominicanus n. sp. Fore wing (3) and hind wing (4). Scale $1 \mathrm{~mm}$.

\section{Taxonomic and Phylogenetic Considerations}

The wing venation of the fossil is similar to that of Mindarus Koch (Mindaridae) and some species of Lizerius Blanchard, Paoliella Theobald and Israelaphis Essig (Drepanosiphidae). A long, pointed pterostigma reaching the apex of the fore wing and a nearly straight radial sector leaving the proximal part of the pterostigma are regarded as archaic or plesiomorphous characters (Baker 1920, Quednau 1974) and were probably present in the common ancestor of the families Mindaridae and Drepanosiphidae, whereas the oncebranched media is a derived or apomorphous character developed from a two-branched media in several aphid groups by parallel evolution or convergency.

Other characters show that the fossil is closer related to Lizerius than to Mindarus. Some of the similarities to Lizerius are probably symplesiomorphies and consequently do not prove relationship, viz. the long cauda and the presence of siphunculi and low tubercles on head and margins of abdomen. Some others must be regarded as synapomorphies, viz. the saltatorial fore legs (thickened fore 

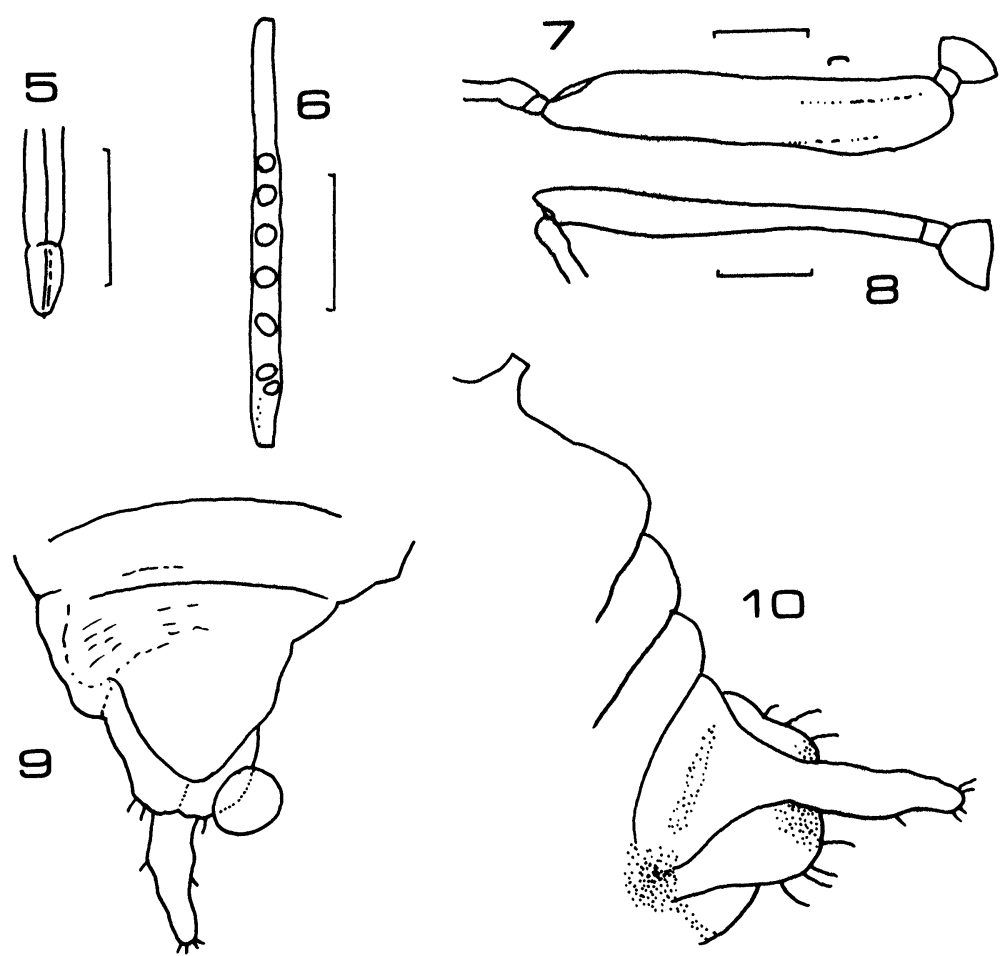

Fig. 5-10. Mindazerius dominicanus n. sp. Distal part of the rostrum (5), antennal segment III with secondary rhinaria (6), fore femur (7), hind femur (8), posterior part of abdomen with cauda and anal plate in an oblique ventral view $(a=$ air bubble) (9), posterior part of abdomen in a dorsolateral view (10). Scales for figs. 5-8 $0.1 \mathrm{~mm}$. (Free-hand drawings).

femora) and perhaps also the triangular field between the posterior parts of the mesothoracic lobes.

The tribe Lizerini was established by Blanchard in 1923, and Paoliellini Takahashi, 1930 is a synonym (Quednau 1974). The diagnostic characters have been listed by Ilharco (1966) and Quednau (1974). Some of them are not visible in the fossil, but the combination of others show its relationship to the Lizerini. Such characters include the presence of frontal tubercles, apparent presence of an epicranial suture, ocular tubercles prominent, fore femora enlarged, apparent presence of membranous triangle be- 


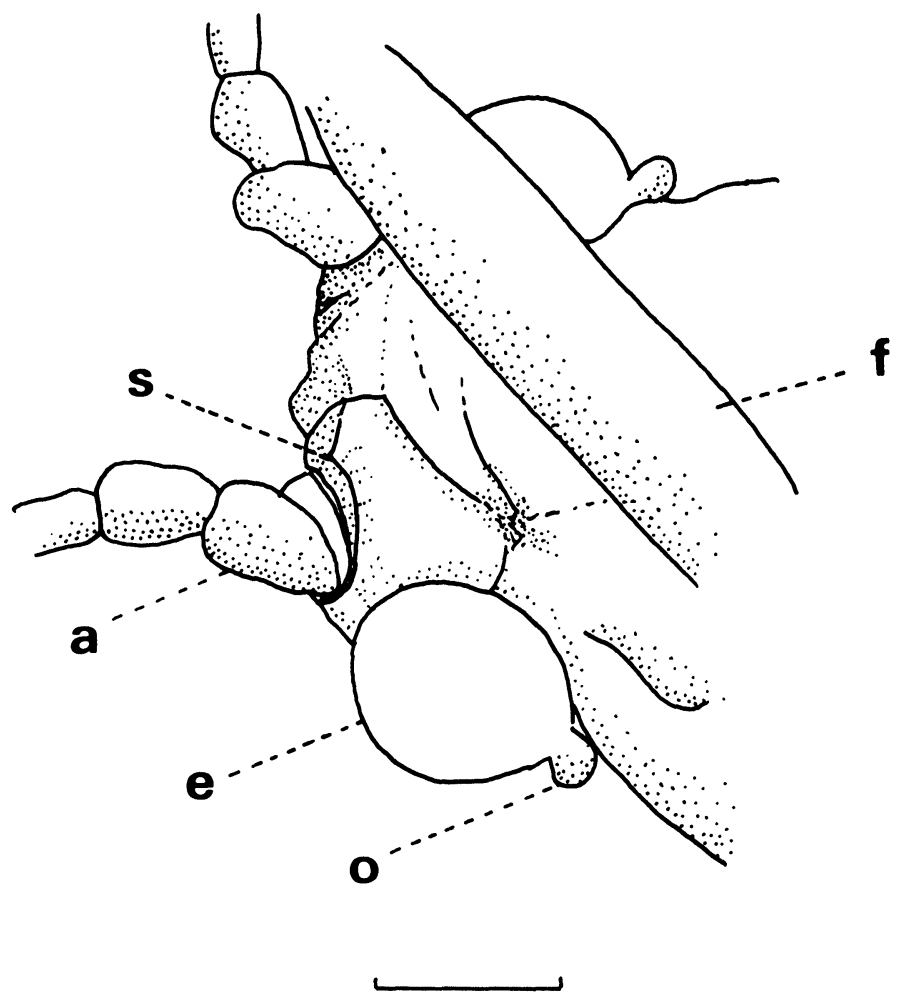

Fig. 11. Mindazerius dominicanus $\mathrm{n}$. sp. Underside of head. Abbreviations: $\mathrm{a}=$ ant. segm. $\mathrm{I}, \mathrm{e}=$ eye, $\mathrm{f}=$ part of fore femur, $\mathrm{o}=$ ocular tubercle, $\mathrm{s}=$ supposed part of epicranial suture. Scale $0.1 \mathrm{~mm}$.

tween the mesothoracic lobes, Mindarus-like venation of wings, abdominal segments I-IV with low and broad marginal tubercles, each with an apical seta, short flangeless siphunculi placed on margins of abdominal segment $\mathrm{V}$, and a long nearly cylindrical cauda.

Mindazerius differs from the two recent genera of Lizerini (Lizerius and Paoliella) in the following characters: cauda not knobbed (it is impossible to see if the cauda is slightly constricted at base or not) and anal plate not deeply incised or bilobed.

Mindazerius resembles Lizerius more than Paoliella. The processus teminalis is short as in Lizerius, while it is prolonged in Paoliella, and the posterior margin of the pronotum is not deeply 
emarginated as in Paoliella, but both similarities between Mindazerius and Lizerius are plesiomorphies, so that they do not indicate that Mindazerius +Lizerius is the sister group of Paoliella. The bilobed anal plate and the knobbed cauda of the recent genera of Lizerini are to the contrary probably synapomorphies showing that Mindazerius is the sister group of Lizerius + Paoliella.

Quednau (1974) discussed the phylogenetic relationships of the Lizerini and concluded that the tribe can be placed nearer some other tribes of Drepanosiphidae (Neophylladini, Neuquenaphidini) than to Mindarus.

\section{BIOLOGY AND ZOOGEOGRAPHY}

It is impossible to determine the host plant of Mindazerius dominicanus, but it is reasonable to assume that it was a woody angiosperm.

Until the Cretaceous, aphids probably lived exclusively on gymnosperms. The fossil record shows that an evolutionary radiation or "explosion" took place as soon as the angiosperms became the dominant group of higher plants. Most recent aphid families are represented in the Cretaceous and Early Tertiary. The Adelgidae, the Mindaridae and some of the Drepanosiphidae, e.g. Neophyllaphis, did never give up gymnosperms (conifers) as their food sources and Prociphilus (Pemphigidae) retained conifers as secondary hosts, but the majority became associated with angiosperms. Some recent genera feeding on conifers today are descendants of aphids, which lived on angiosperms in the past, e.g. Elatobium (Aphididae) and Cinara (Lachnidae).

The first Lizerini, among these Mindazerius, may have lived on conifers. Although no remains of conifers have yet been described fom Dominican amber, a pine (Pinus occidentalis), juniper (Juniperus gracilior) and Podocarpus Buchii are indigenous species present today in the Dominican Republic (General Secretariat, 1969). The former species covers some 215,500 hectares or $4.5 \%$ of the country with the heaviest stands in the Cordillera Central and Sierra de Bohoruco.

IR is, however, more reasonable to assume that the host plant was a woody angiosperm because most recent groups of Drepanosiphidae feed on angiosperms, which are known from the Early Tertiary. The Drepanosiphidae was a dominant family in Early Tertiary, and 
some of the fossil species resemble modern drepanosiphids living on Acer and other angiosperms (Heie, 1967). Recent Lizerini feed on various families of angiosperms, including Combretaceae, Lauraceae, Nyctaginaceae and Burseraceae. Remains of angiosperm families which have been found in Dominican amber include representatives of the Leguminosae, Meliaceae, Myristiaceae, Actinidiaceae, Bombaceae and Hippocrateaceae (Poinar, unpublished data). The amber-producing plant, Hymenaea, need not be the host of the aphid since the latter is winged and could have flown or been blown into the resin.

The climate of the locality in the Miocene-Eocene period was tropical, warmer than the regions where Mindarus spp. occur today, but much like the climate where species of Lizerius and Paoliella live. It is interesting that the present distribution of Lizerius is Neotropical, since the continuous tropical climate may be the reason why Mindazerius and most other groups of fossils in Dominican amber still have relatives in South America today.

The geographical distribution of Lizerius (South America) and Paoliella (Africa, India and South America) suggests that Lizerini originated in the southern hemisphere in the Late Mesozoic, when the Atlantic Ocean did not represent an obstacle to dispersal. The occurrence of a fossil relative in Dominican amber does not invalidate this idea.

\section{AfFinities}

The oldest known fossil aphid with a similar wing venation to Mindazerius is Nordaphis sukatchevae Kononova from the Cretaceous Taymyrian amber in the USSR. Kononova (1977) placed it in Lizerini, but her drawing suggests that it could also belong in the Mindaridae (Heie 1987). With Mindazerius, which is more similar to Lizerius than to Mindarus, Nordaphis could well be a relative of Lizerius and of Mindarus. Nordaphis may be a specialized representative (with an extremely long rostrum) of a group related to the ancestor of Lizerini or the ancestor of both Drepanosiphidae and Mindaridae.

If Mindazerius dominicanus had had the fore legs, the siphunculi and the long cauda missing - then it probably would have been placed in the Mindaridae. All Tertiary aphids with that kind of wing 
venation have been described as species of Mindarus, but could some of them belong to the Lizerini?

Five fossil Mindarus species have been described, viz. three from Baltic amber, M. magnus Baker, M. parvus Heie and M. transparens (Germar \& Berendt) (Heie, 1968; 1971), and two from the Oligocene clay at Florissant, Colorado, $M$. recurvus (Buckton) and $M$. scudderi (Buckton) (Heie, 1967; 1985).

The three amber species belong without doubt to Mindarus. None of them have saltatorial fore legs. The cauda is visible in parvus (Heie, 1967) and one specimen of magnus (Heie, 1969), and is short as in recent Mindarus spp. M. parvus shows on one side a short, cylindrical structure partly covered by an impurity. It is, however, not a siphunculus, but probably the border of a drop of secretion from a siphuncular pore. The differences between parvus and the recent species abietinus are so small that parvus in fact may be regarded as a dwarf form of abietinus or one of the other still living species.

The siphuncular pores and cauda of the two species from Florissant are invisible. The legs are badly preserved, but the general appearance is much like Mindarus. Both are very large, body length being about $3 \mathrm{~mm}$ in scudderi (Buckton) and $4 \mathrm{~mm}$ in recurvus (Buckton). Some of the Mindarus specimens in Baltic amber are of similar size, while all Lizerini are rather small aphids.

Mindaridae is the only extant aphid family containing more fossil than recent species. The family has apparently changed very little since the Eocene since the differences between the fossil and recent species are small, although representatives showed greater diversity in the Early Tertiary than they do now. The three or four recent species which now occur in temperate North America and Eurasia, are "living fossils." They include M. obliquus (Cholodkovsky) on Picea in Eurasia, M. abietinus Koch on Abies in Europe and North America, M. japonicus Takahashi on Abies in East Asia, and $M$. victoria Essig on Abies in North America. Some of these names are probably synonyms. The difference between $M$. abietinus and $M$. japonicus is so small that they may be geographical races of one species (Heie, 1967, p. 34). The former has 12-27 secondary rhinaria on antennal segment III, while the latter has 24-37 secondary rhinaria. We have not seen material of $M$. victoria. 
Sigmacallis pilosa Zhang from Populus in China perhaps belongs to the Mindaridae according to Zhang \& Zhong (1981) although its pterostigma is rather short, not reaching to the tip of the wing.

Lizerini is a tribe within the subfamily Drepanosiphinae, family Drepanosiphidae (Heie, 1980). Among its archaic characters is the presence of scent plaques ("pseudosensoria") on all tibiae of the oviparous morph, not only the hind tibiae. The apterous morphs carry "chamois-horn-like" processes as the extinct Palaeosiphon hirsutum (Germar \& Berendt) (the oviparous female of which also has scent plaques on all tibiae) from Baltic amber (Heie, 1967) and some recent representatives of various tribes of Drepanosiphinae, e.g. Eonaphis Quednau from Africa and Neuquenaphis Essig from South America. Until now 30 recent species of Lizerini have been described, 9 species of Lizerius and 21 species of Paoliella. Not all Lizerini have wings like Mindarus. The pterostigma does not quite reach the apex of the wing in Lizerius intermedius Quednau, $L$. costai Quednau and some others. Mindazerius dominicanus resembles $L$. cermelii Quednau (on Bougainvillea in Brazil) very much in respect to wing venation and some other characters.

\section{SUMMARY}

The first fossil aphid from the Neotropics, Mindazerius dominicanus nov. gen., nov. sp., is described from Dominican Republic amber. It is placed in the tribe Lizerini of the family Drepanosiphidae (Aphidoidea) and shares characters with the genera Mindarus and Lizerius. Major features of the fossil include the long pterostigma of the fore wing the truncate siphunculi, long cauda and strongly thickened fore femora. Biological and zoogeographical implications, as well as affinities with both fossil and recent relatives, are presented.

Key words: Aphid, Lizerini, Drepanosiphidae, Mindaridae, fossil, phylogeny, palaeontology, Dominican amber.

\section{Literature Cited}

BAKER , A. C. 1920. Generic classification of the hemipterous family Aphididae. U.S. Agric. Bull. 826: 1-93.

Blanchard, E. E. 1923. A new aphidian tribe from Argentina. Physis 7: 120-125.

Eberle, W., Hirdes, W., Muff, R. \& Pelaey, M. 1980. The geology of the Cordillera Septentrional. Proceedings of the 9th Caribbean Geological Conference, August, 1980, pp. 619-632. Santo Domingo, Dominican Republic. 
General Secretariat (Organization of American States). 1969. Survey of the Natural Resources of the Dominican Republic. Washington D.C. 305 pp.

HeIE, O. E. 1967. Studies on fossil aphids (Homoptera: Aphidoidea), especially in the Copenhagen collection of fossils in Baltic amber. Spolia zool. Mus. Haun. 26: $1-274$.

HeIE, O. E. 1968. An aphid identified with Aphis transparens Germar \& Berendt, 1856, and some other Baltic amber aphids in German collections. Stuttgarter Beitr. z. Naturkunde 184: 1-7.

HeIE, O. E. 1969. Aphids in the Berendt collection of amber fossils in Berlin (Homoptera: Aphidoidea). Dtsch. Ent. Z. N.F. 16: 175-183.

HeIE, O. E. 1971. The rediscovered types of the fossil aphids described by Germar and Berendt in 1856. Dtsch. Ent. Z. N.F. 18: 251-264.

HeIE, O. E. 1980. The Aphidoidea (Hemiptera) of Fennoscandia and Denmark. I. General part. The families Mindaridae, Hormaphididae, Thelaxidae, Anoeciidae, and Pemphigidae. Scandinavian Science Press Ltd., 236 pp.

HeIE, O. E. 1985. Fossil aphids. A catalogue of fossil aphids, with comments on systematics and evolution. Proceedings of the International Aphidological Symposium at Jablonna, 1981, Polska Akademia Nauk, pp. 101-133.

HeIE, O. E. 1987. Palaeontology and phylogeny. Chapter 6, part 1, in Harrewijn, P. \& Minks, A. K. (ed.): "Aphids. Their Biology, Natural Enemies and Control." In the series "World Crop Pests," vol. 2 A, Elsevier, the Netherlands, pp. 367-391.

Hueber, F. M. \& Langenheim, J. 1986. Dominican amber tree had African ancestors. Geotimes 31: 8-10.

IlHaRCo, F. A. 1966. A study on the systematic position of the genus Israelaphis Essig, with descriptions of the alate forms and the first instar nymphs of Israelaphis lambersi Ilharco (Homoptera-Aphidoidea). Agronomia Lusitana 26: 257-272.

Kononova, E. L. 1977. New species of aphids (Homoptera, Aphidinea) from the Upper Cretaceous deposits of Taimyr. Revue d'Entomologie de l'URSS 56: 588-600.

Lambert, J. B., Frye, J. S. \& Poinar, G. O. 1985. Amber from the Dominican Republic: analysis by nuclear magnetic resonance spectroscopy. Archaeometry 27: 43-51.

Poinar, G. O. 1982. Amber - true or false. Gems and Minerals 534: 80-84.

PoInAR, G. O. 1988. Hair in Dominican amber: Evidence for Tertiary land mammals in the Antilles. Experientia 44: 88-89.

Poinar, G. O. \& Cannatella, D. C. 1987. An Upper Eocene frog from the Dominican Republic and its implication for Caribbean biogeography. Science 237: 1215-1216.

Quednau, F. W. 1974. Notes on the Lizerini Blanchard with descriptions of new Lizerius and Paoliella species from South America and Africa (Homoptera: Aphididae). Can. Ent. 106: 45-72.

Zhang, Guang-Xue \& Zhong, Tie-Sen. 1981. Homoptera: Aphidoidea. Insects of Xizang 1: 233-282. 

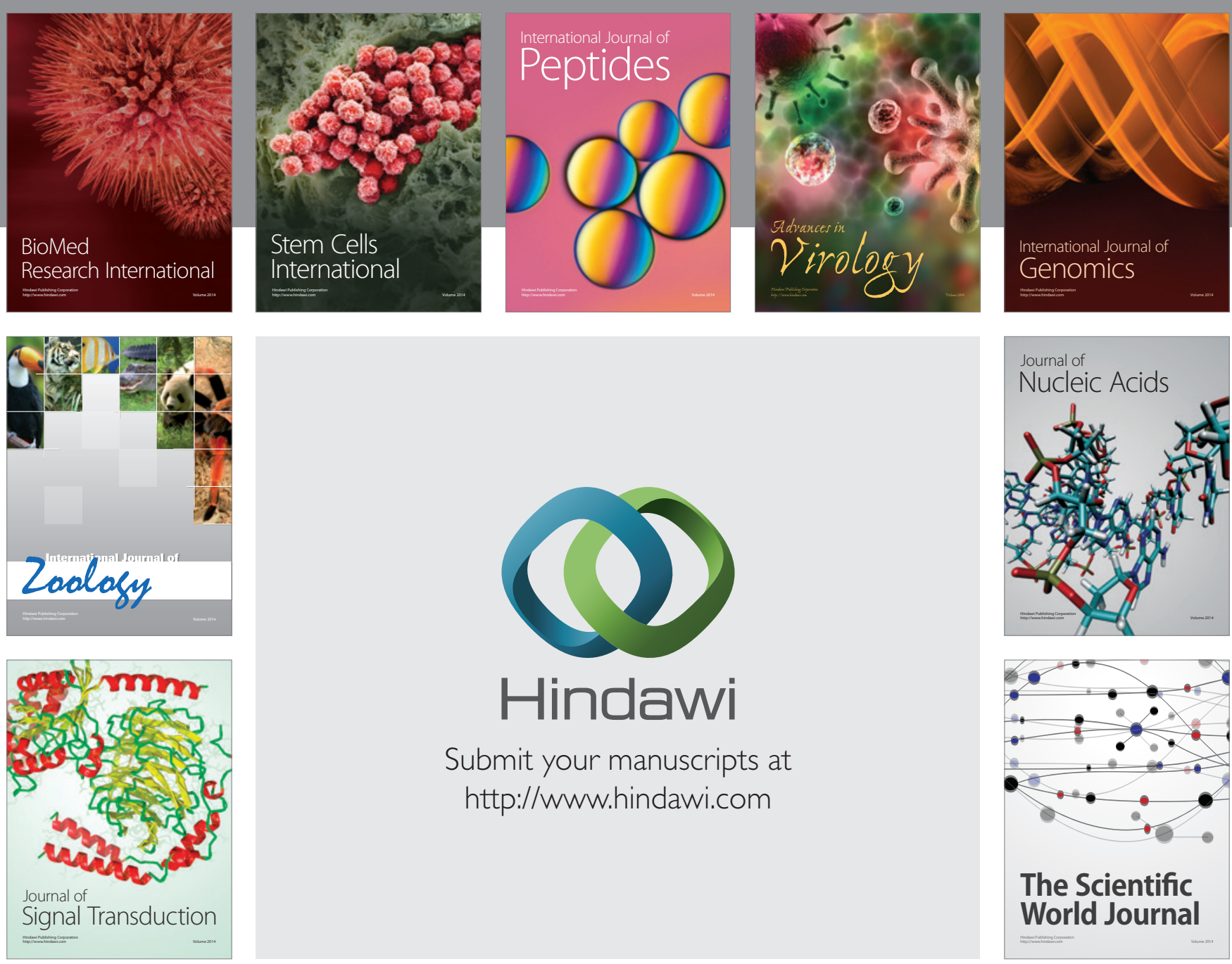

Submit your manuscripts at

http://www.hindawi.com
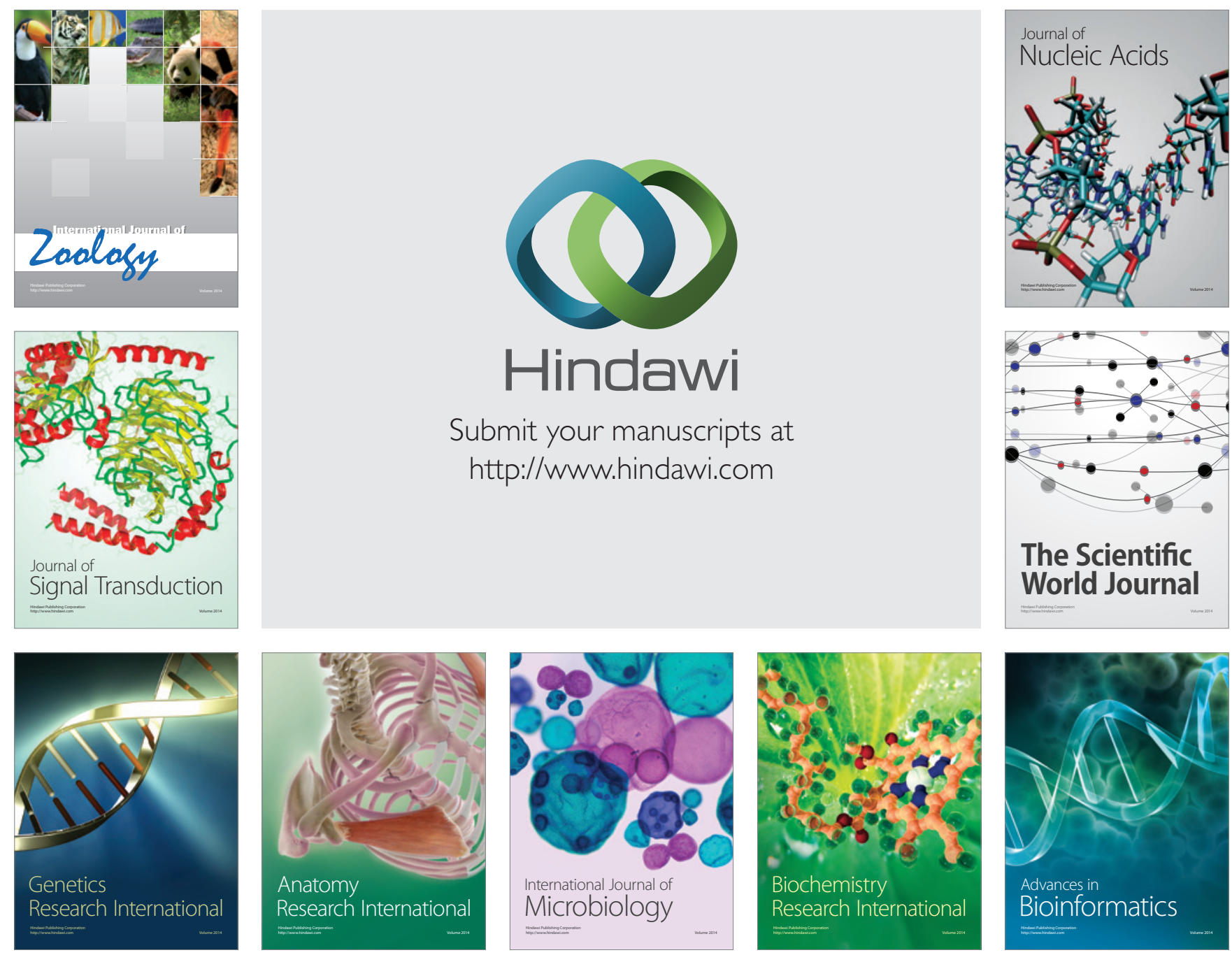

The Scientific World Journal
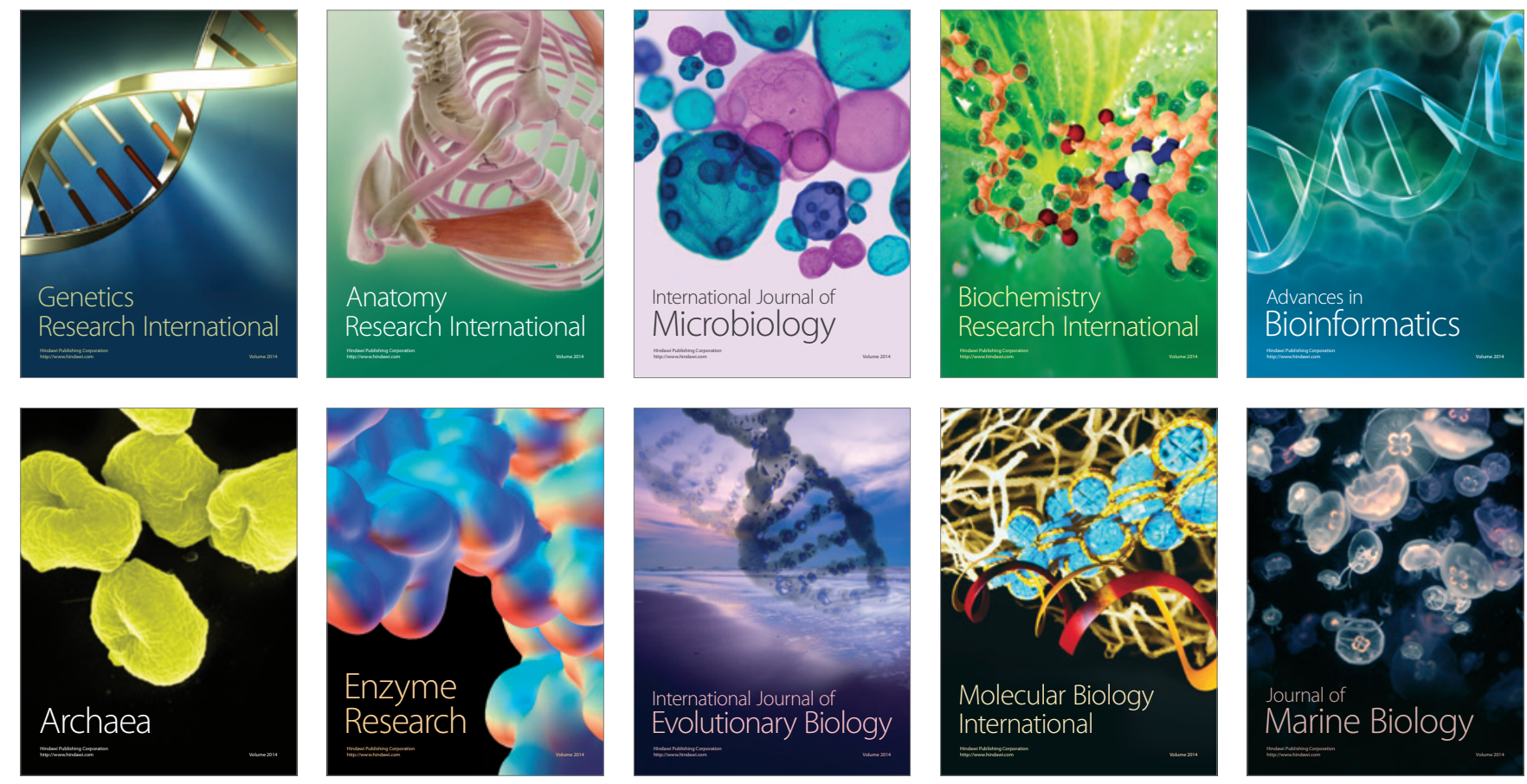